\title{
The effect of location-based game on the learning of seniors in the field of information and communications technologies
}

\author{
Ewa Jurczyk-Romanowska \\ Jacek Gulanowski \\ Aleksandra Marcinkiewicz \\ University of Wrockaw \\ Faculty of Historical and Pedagogical Sciences \\ ewa.jurczyk@uni.wroc.pl
}

DOI:10.5901/mjss.2014.v5n19p395

\begin{abstract}
The paper discusses the results of a single educational experiment which aimed to evaluate the effectiveness of the use of location based-game in the education of seniors. The participants took part in classes on the use of video games console PlayStation 3. 57 senior (over 60 years of age) learners took part in the study. They have been randomly assigned to control and experimental groups. The control group took part in traditional classes and the experiment group took part in locationbased game. The aim of the study was to answer the research question: Does the learning of information and communications technologies by seniors with the use of location-based game improve the quality of learning (indicated by the time of realising the task, number of questions asked during the realisation of the task, seniors' evaluation of the technology, of the classes and of their own competences)? Seniors evaluated the classes, the technology and their own competences by means of original questionnaire consisting of grading attractiveness, usefulness and difficulty of the class and the technology, and grading their own ability to use the technology, the want to use the technology and the recommendation of the technology to others. As the results of the experiment indicate the learning of information and communications technologies by seniors with the use of location-based game improves the quality of their learning. The use of location-based game increases significantly the pace of assimilation of the knowledge by the learners as indicated by the time of realising the task. It also increases the level of self-reliability of the learners as indicated by the number of questions asked during the realisation of the task. However, it does not affect learners' perception of the technology, the classes and their own competences as is indicated by the evaluation.
\end{abstract}

Keywords: Location-based game, Information and communications technologies, ICT skills, adult education, seniors, late adulthood, experiment, educational experiment

\section{Theoretical background of the experiment: the aging society}

The beginning of the 21 st century is characterised by the dynamics of the information and communications technologies development, the distinction of the real and the virtual spheres of human life, significant demographical shifts, namely the aging of society, and consequently: the ever more alarming civilisation exclusion of elderly persons. As a response to those shifts a number of actions have been undertaken on the international level - for instance the naming of the year 2012 as the European Year of the Activity of Elderly Persons and Intergenerational Solidarity. Another example is the undertaking of comparative research of the Active Ageing Index. An example on the national level is the creation of the Government Programme for the Social Activity of Elderly Persons for the years 2012-2013. However, the correct manner of planning of social activities is conditioned by the previous scientific research analysing the question of the exclusion of the elderly persons and the methods of counteracting this exclusion. The undertaking of such research in Poland is a necessity, especially considering the fact that in the European ratings of the activity of elderly persons our country occupies the last position, as is appointed for instance by the European Commission Report Eurostat 2012 Active ageing and solidarity between generations. A statistical portrait of the European Union 2012 (p. 20).

A key aspect of the discussion of the aging of society is demography, the essence of which is reproduction of the population. The relationship of fertility and mortality is of crucial importance, as the uncertainty of survival has always lay heavy on 
mankind. It was the control and suppression of the recurring mortality catastrophes between the 16 th and the 20 th century as well as the significant elongation of human life which caused the end of the threat of extinction.

The theory of demographic transition is fundamental for the understanding of the processes of population aging. According to the theory, demographic transition is the replacing of a population with radical, lasting and irreversible drop in mortality and rise in fertility by a population with a low intensivity of those processes (Coldwell, 2006, pp. 307-308). Western European countries have first reached the phase in which the reproductive success is free of the threats connected with uncontrolled mortality. Thus, it was expected that reproduction will be permanently stable after reducing mortality to biological minimum and reaching the state of basic replacement rate. In reality demographic transition has caused deep quantitative and structural changes in the population. Despite favourable biological and social conditions contemporary societies are far from reproductive success (Okólski, 1997, pp. 25-55).

Due to insufficient procreation, contemporary societies are facing lasting and fundamental depopulation, the effect of which is the aging of societies. Globally the number of people over 60 years of age in the population has risen from $8 \%$ in 1950 to $12 \%$ in 2013. Whereas in 2050 the number of older persons is estimated as 2 billions, which will constitute $22 \%$ of population (World Population Aging, 2013, p. 11). At that time the number of old people will be the same as the number of children. That is the reason of population aging becoming one of the most important problems of the modern world.

The issue of research on old age is currently more and more often raised in various scientific studies; however, it is mostly done on the theoretical plane, through description of the phenomenon of aging and old age, the image of the elderly persons, the potential of seniors life experience, which is without doubt a crucial output of science. The problem of old age and human aging has become one of the main fields of interest of the researchers of the domain of social sciences, humanities, economics or medical sciences. In the domain of pedagogy and other social sciences the questions most often raised are: the support and the advancement of quality of life of the older persons (Bond \& Corner, 2004; Halicka1997), social and cultural activity of seniors (Victor, Scambler \& Bond, 2009; Semków 2000; Halicka, Halicki, 2003), gerontological prophylaxis (Czerniawska, 2007), social (Bond \& Corner, 2004; Ziębińska 2010) and economical situation of older persons (Zach, 2001). Nevertheless, the education of older persons for the informational society is still a little researched issue.

\section{Education of seniors in the field of information and communications technologies}

Before turning to the issue of the use of information and communications technologies by seniors, the term itself demands a definition. James Murray defines information and communications technologies (ICT) as "the integration of telecommunications, computers, middleware and the data systems that support, store and transmit UC [united communications] communications between systems" (Murray, 2011). According to the Free On-line Dictionary of Computing ICT is: "The study of the technology used to handle information and aid communication" (Information and Communication Technology, 2008). Thus, the specific technical devices, their use and study of those technologies can be considered information and communications technologies.

The problem of the using of information and communications technologies by the seniors has been raised by the researchers and its effect is the report of Ewa Frackiewicz. The effect of internet on the activity of seniors form the perspective of the strategy of building information society i2010. The results of the report unambiguously prove that older persons are threatened by digital exclusion. Furthermore, the research shows that the students of Universities of Third Age use computer and internet more often than other seniors who do not participate in extra-formal education. Results of this research have also proved the argument that seniors use the information and communications technologies to a lesser extent than younger persons. Nevertheless, the research presented in the report has focused only on the use of computer and internet, omitting smartphones, tablets, cash dispensers etc. It must be also emphasised that the research was concerned only with the opinions and attitudes of seniors towards computers and internet. The questions of using information and communications technologies by older persons has been also raised in the research of Beata Ziębińska (2010, p. 274-276). The results of the research of this author show, that computer classes take place in over half of the studied Universities of Third Age. Nevertheless, the research points out only to the fact, whether a certain UTA offers such classes. Both the research of E. Frackiewicz as well as B. Ziębińska attempt to estimate the level of using of information and communications technologies and the availability of computer classes, but in both cases the research had a quantitative character and was limited to the diagnosis of the actual state of affairs. Thus, the need to undertake research of the effectiveness of certain forms of education of seniors in the field of information and communications technologies is visible.

As the research on the counteracting of the digital exclusion of seniors should not only be still conducted but also broadened to the widely-understood information and communications technologies and innovative educational methods the authors of 
this paper have undertaken the activity as a part of the Group of Research of Games and ICT in Education "Edutainment" founded in the May of 2013. The team's field of research is education of adults in the field of/with the use of information and communications technologies and games.

The inspiration for undertaking such a scientific research were the previous experiences of the authors (most of the members of the research team)- in the work with elderly persons realised as a part of the projects: Nestor and @ktywny Senior (@ctive Senior). Those experiences were of scientific and practical character, as on the one hand the participants of the project took the roles of teachers and instructors of classes for the elderly and on the other hand they carried out research on education of elderly persons. The experiences of the research team have been compiled in the publication: The Third Shift. Andragogical Reflections on the @ktywny Senior Project, publication of which was financed by the Lower Silesian Centre of Social Help in Wrocław. The book has been considered the Lower Silesian handbook of senior activity by the Marshal Office if the Lower Silesian Voivodship 1. In this book the authors have presented in the form of academic study and good practices the traditional methods of education of seniors, which have been adapted as NGOs as examples of good practices and are still being used as part of various projects aimed at information education of seniors .

However, during their further activity members of the research team observed that traditional methods in education of seniors are effective, but they do not improve self-reliability of seniors: they are strictly instructions. Furthermore, seniors have often asked those same questions, each time expecting the instructor to help them. On the other hand, single use of the method of location-based game (purpose of which was teaching of elderly persons of using the media library in Wrockaw) have brought better results in affecting the self-reliability of seniors. On this basis a hypothesis was formulated that the use of the method of location-based games in education of seniors improve quality of learning. A one-time class does not entitle formulation of any scientific conclusions, thus, we decided to carry out an educational experiment, the aim of which would be verification of the previously formulated hypothesis and acquirement of an answer to the question: what is the impact of use of the method of location-based games on the elderly persons' mastering of the use of information and communications technologies.

In this context the location-based game as a form of education of seniors seems to be an especially interesting field of research. Mostly it must noted that academic research on the location-based games as a not traditional method of education has not been so far undertaken. Thus, it will enable the comparison of the effectiveness of traditional methods of education with the innovative ones. Additionally, Adult Learning in the Digital Age. Information technology and the learning society presents the results of research on the education of adults in the context of information and communications technologies. The aim of the research was (among others) the description of how adults learn with the use of information and communications technologies. It has been observed that adults often learn the use of new technologies during realisation of everyday tasks, which demand the use of a certain technology. Thus, the educational aim of the mastering of information technologies is a side-effect of everyday tasks which are not directly aimed at learning. Those conclusions justify the use of location-based game, which is based on the principle of learning incidentally by realising various tasks. Furthermore, the participation in location-based game creates for seniors the possibility of entering new social relations and creating nets of informal contacts. As it is indicated by the British research of social lives of the elderly, social engagement of seniors and such nets of informal contacts affect not only their loneliness but also minimises the risk of social marginalisation (Victor, Scambler \& Bond, 2009).

The distinction of traditional methods (based on the realization of aims and tasks of teaching, familiarisation of students with new material, generalisation and consolidation of new material, forming skills and habits, as well as binding of theory with practice and control of the effects of teaching) and modern (based on the formulation of problem, motivating students to work, assimilation, exploration, experience and action as means of studying, and on solving a problem and the final acknowledgement of the output of the realised classes) has been done after B. Niemierko (2003, p. 186). Location-based games can be considered modern methods of teaching (which can be also described as innovative). Location-based games are defined as a form of pastime activity, a significant element of which is the space with its various contexts, merging the features of paper chase, happenings and computer games as well as RPG (www.gramiejska.pl). Three kinds of locationbased games are distinguished: hobby (events of which participants are people fascinated with the theme), commercial (organised by companies specialised in team-building or marketing, which aims are integration or advertisement of a given product) and educational (which aim is the transmission of knowledge or skills) (Krzemińska, n.d.).

1 The book has met with a large audience especially among seniors who have on numerous occasions asked the authors to organise further, broader and more advanced courses. The book has been also an inspiration for the seniors of Koło to found their own UTA named "Third Shift" tu underline the desire of the people involved to use information and communications technologies. 


\section{Methodology of the experiment}

Method that was used in the research was educational experiment. Techniques that were used in the experiment were: location-based game and traditional class. The topic of the class organised for the experiment was: the use of video games console PlayStation 3.

The research questions were formulated on the basis of the existing literature and the previous experience of the researchers in working with seniors.

The main research question was: Does the learning of information and communications technologies by seniors with the use of location-based game improve the quality of learning (indicated by the time of realising the task, number of questions asked during the realisation of the task, seniors' evaluation of the technology, of the classes and of their own competences)?

The following three detailed research questions were also formulated:

Did the method of teaching affect the effectiveness of learning of the participants?:

Did the method of teaching affect the pace of assimilation of the knowledge by the participants?

Did the method of teaching affect the level of self-reliability of the participants?

Did the method of teaching affect the perception of the class by the participants?

The independent variable that set for the experiment was the method of teaching, either traditional or experimental (locationbased games).

The dependent variables which were chosen for the research were: the pace of assimilation of the knowledge by the participants, their level of self-reliability, their perception of the class.

The indicators which were set for these variables were: time of realising the task (for the pace of assimilation of the knowledge), number of questions asked during the realisation of the task (for the level of self-reliability), evaluation of the class: its attractiveness, usefulness and difficulty (for the perception of the class).

Basing on the literature and the previous experience of the researchers, the following hypotheses were formulated regarding correlation of independent variable with the dependent variables:

The method of teaching correlated with the pace of assimilation of the knowledge by the participants. (The participants from the experimental group assimilated the knowledge faster than the participants from the control group).

The method of teaching correlated with the level of self-reliability of the participants. (The participants from the experimental group have been more self-reliable than the participants from the control group).

The method of teaching correlated with the perception of the class. (The participants from the experimental group evaluated the class as more attractive, more useful and less difficult than the participants from the control group).

\section{The experiment}

For the purpose of the research presented in the project, members of the research team have designed location-based game which aim was to answer the question: Does the learning of information and communications technologies by seniors with the use of location-based game improve the quality of learning? For the needs of the experiment we have decided to choose a technology with which the participants had not had any contact so far, namely: video games console PlayStation 3.

The experiment was conducted on 18th-20th and 25th of November 2012 in Wrocław. The experiment was realised in the multimedia room of the Empik salon in Dom Handlowy "Renoma" in Wrocław (Poland). Empik is a Polish chain multimedia and books store and it was a partner of the project.

Participants of the experiment were seniors recruited with the help of Universities of Third Age in Wrockaw (although not all of them were students). The overall number of participants was: 57.

The participants of the experiment were divided into two groups: the control group and the experimental group. Both groups had to learn the basics of the use of PlayStation 3 and realise three tasks. The control group was firstly instructed by one 
of the researchers on the use of PlayStation 3 and then had to realise the tasks on their own. The experimental group had to learn the basics and then realise the tasks with the use of location-based game designed specifically for this experiment. Eventually, there were 32 participants in the experimental group and 25 participants in the control group.

Both groups were handed a printed short manual of the use of PlayStation 3. The control group firstly went through the manual with the instructor, the experimental was just handed the manual and could use it on their own.

The three tasks were:

1. finding the folder "Architecture" and watching pictures that were saved in it;

2. finding the folder "Music" and creating a playlist consisting of three songs;

3. finding the folder "Films" and playing the film "Journey".

During the location-based game the participants firstly gathered in the Dom Handlowy "Renoma" shopping mall outside of the Empik bookstore. They were met by one of the instructors who introduced to the idea of the game. Later they were given an envelope which contained the introduction to the game. They were supposed to play the role of seniors who are expecting friends and wish to organise a "Cyber-Senior" party during which they would show pictures to their friends, listen to music and watch a film. Then, they had to find further instructions and the manual hidden behind one of the books in the Empik bookstore, later find the PlayStation 3 consoles and then realise the tasks.

Both groups were realising the tasks on their own, however the researchers-instructors were present and the participants could freely ask them questions regarding their work. Also after realisation of every task the participants had to call one of the researchers-instructors who would then check the realisation of the task.

The researchers noted the time of completion of the tasks by each group and the number of questions asked, although the participants were not informed about this fact.

After the realisation of the task participants also filled out a survey in which they had to evaluate (by ascribing points to each category) the class (attractiveness, usefulness and difficulty).

The participants also answered the following open questions:

1. What is your opinion of today's class?

2. What is your opinion of the technical aspect of the class?

3. Which elements of the class did you like?

4. Which elements of the class you did not like? Which ones would you change?

\section{Results}

Statistical analysis enabled the verification and falsification of the hypotheses and answering the research questions. The data was analysed with The one-way multivariate analysis of variance (one-way MANOVA). The results are presented in the following table.

Table 1. Verification of the hypotheses

\begin{tabular}{|l|l|}
\hline Hypothesis & Outcome \\
\hline $\begin{array}{l}\text { 1. The method of teaching correlated with the } \\
\text { effectiveness of learning of the participants. }\end{array}$ & $\begin{array}{l}\text { 1. Verified: The innovative method of teaching (location- } \\
\text { based game) increased significantly the effectiveness of } \\
\text { learning by the participants. }\end{array}$ \\
$\begin{array}{l}\text { a) The method of teaching correlated with the pace of } \\
\text { assimilation of the knowledge by the participants. }\end{array}$ & $\begin{array}{l}\text { a) Verified: The innovative method of teaching (location- } \\
\text { based game) increased significantly the pace of assimilation } \\
\text { of the knowledge by the participants. } \\
\text { b) Verified: The innovative method of teaching (location- } \\
\text { based game) increased significantly the level of self- } \\
\text { reliability of the participants. }\end{array}$ \\
$\begin{array}{l}\text { b) The method of teaching correlated with the level of } \\
\text { self-reliability of the participants. }\end{array}$
\end{tabular}


2. The method of teaching correlated with the perception of the class.
2. Falsified: The method of teaching did not correlate with the perception of the class.

There was a statistically significant difference in the effectiveness of learning by the participants, $F(5,51)=17,26, p<$ $.0005 ;$ Wilk's $\Lambda=0.372$.

Additionally, the answers to the open questions were analysed.

To the question: "What is your opinion of today's class?" the most common answers were: "positive", "very good".

The most noteworthy positive comments were: "I was for the first time in [sic!] PlayStation and for the first time I held it in my hands. For me it is a novelty and attaining new skills"; "The technique is not a problem if we learn it before we start"; "Leaving the student alone with the equipment and forcing him to experiment is the highest point of today's class. The discreet participation of the instructors has helped in fast learning of the equipment. For me - excellent".

The most noteworthy negative comments were: "OK. But I would prefer to practice alone; 2 controllers cause »distracting" each other"; "In my opinion the first envelope and playing to find instructions was useless. It is more for children. For us concrete. Equipment”; "Due to limited hearing (hearing aid) and difficulties in reading the instructions and the misunderstanding of the instructors (lack of computer skills) it was difficult for me to fulfil the tasks"; "I grade my skills as still low"; "Only for select seniors"; "Could have been more difficult".

To the question: "What is your opinion of the technical aspect of the class?" the most common answers were: "very good" and "good".

The most noteworthy positive comments were: "Outstanding. Very interesting and educational multimedia classes. I thank you very much for the invitation and enabling me to learn how to use the console"; "Very good preparation"; "Super: lots of envelopes, nicely printed tasks, fine "supervision « of the participants"; "Good instructions on the use of the console. It is rare among instructions"; "Nice atmosphere".

The most noteworthy negative comments were: "As always the equipment tends to be mean"; "The instruction was not clear"; "1 person per each console".

To the question: "Which elements of the class did you like?" the most common answers were: "all", "slides", "photos", "console".

The most noteworthy positive comments were: "Playing films and slides"; "Searching for places where the instructions were hidden. Unassisted turning the equipment on"; "Slideshow, playing music"; "Everything is very interesting and I would like to learn other possibilities, such as: games"; "Making playlists"; "Perfect preparation of the instructors, help of the instructors"; "Doing things according to instructions, the possibility to watch interesting things, searching for tips"; "Group work"; "Help of the instructors"; "Cordial and professional staff as well as patience and forbearance"; "Large screen".

The most noteworthy negative comments were: "They have solidified my belief that for certain tasks certain equipment must be chosen"; "It is hard for me to work in a group".

To the question: "Which elements of the class you did not like? Which ones would you change?" the most common answers were: "nothing", "none", "work in groups", "technical problems".

The most noteworthy positive comments were: "Keep it up!"; "Classes stimulated the perceptive skills, exercising the memory of seniors etc."; "I am happy I learned the use of console. I don't have any proposition of changes as I am not competent in this field"; "None. Don't change anything!".

The most noteworthy negative comments were: "Technical problems with the equipment, not working console"; "There was a technical problem with the equipment, it should have been checked before"; "Mechanical reproduction"; "Not creative classes", "I would choose a different set of tasks, more adjusted to the specific character of the console, letting to learn the equipment more"; "I didn't like that two people used the same controller at once! They annoyed each other"; "The instruction of making the playlist (music) was not clear", "The participants should get to know each other better!".

It can be said that the comments were mostly positive (as the evaluation of the classes by points) but the devil is in the details. Firstly, when comparing evaluation by points with open questions it turns out that the participants in most cases have written positive comments even if their evaluation indicates that they did not really like the class. We suspect that participants might have written nice comments as a way of expressing their gratitude for the instructors who have organised 
something for them for free, but they might have been more honest while evaluating the classes by ascribing points. Secondly, the comments are contradictory. The participants liked and disliked the location-based game, they liked and disliked the equipment, they thought that the instructions were clear and that they were not clear etc.

However, it must be emphasized that majority of the participants enjoyed and liked the classes (as is indicated both by the evaluation and answers to open questions) regardless which group (experimental or control) they were part of. Also, what has been considered as the most positive fact (nobody has listed this in negative comments) was the over-all atmosphere of the classes and the attitude of the instructors, which as is indicated by previous experience is a matter very important for seniors. What has been listed as the most negative aspect were the technical problems, which can be interpreted as either real technical problems but also as the effect of participants' anxiety in the first contact with a completely unknown technology.

\section{Conclusions}

As the results of the experiment indicate the learning of information and communications technologies by seniors with the use of location-based game improves the quality of their learning.

The use of location-based game increases significantly the effectiveness of learning by the participants. It increases significantly the pace of assimilation of the knowledge by the learners as indicated by the time of realising the task. It also increases the level of self-reliability of the learners as indicated by the number of questions asked during the realisation of the task. However, it does not affect learners' perception of the classes as is indicated by the evaluation.

There were some difficulties that the researchers faced during the conducting of the experiment. The first problem that we encountered during the recruiting process of the participants was the fact that when the participants heard about the aim of the experiment (which was not kept secret) they all wanted to participate in location-based games. Thus, it was decided that we would not inform them which groups are control and which are experimental. The other problem was the absence of some of the participants who just did not show up at the classes without informing the researchers beforehand. Thus, it was difficult to keep the number of people in both control and experimental groups even. There was also a problem with the understanding of the questionnaire by the participants, which they were supposed to fill out on their own, however they consulted each other and sometimes asked the researchers for help, even going beyond asking for further instructions and asking what exactly they should write.

The results indicate that the location-based game is an effective method of teaching information technology skills for seniors, however it was only a single experiment with a small number of participants. A modified experiment aimed at determining whether location-based game is an effective method in senior education in the field of IT should be carried out, this time with more classes on different topics (related with IT) and on larger and even number of participants.

\section{Acknowledgements}

The authors would like to thank the following persons and institutions:

Empik bookstore for letting us conduct the experiment using the rooms and equipment of the bookstore;

University of Third Age in the University of Wrockaw and University of Third Age of the Academy of Physical Education in Wrockaw for their help and involvement in the recruitment of participants of the experiment;

Natalia Romanowska and Outspider for the organisation and coordination of the recruitment of the participants, as well as active involvement in the planning of the location-based game and realisation of the experiment;

Dariusz Błaszczak for his advice and help with the statistical analysis of the data;

Ilona Zakowicz and Agnieszka Gil for their help in conducting the experiment;

Members of the Group of Research of Games and ICT in Education "Edutainment": Ewa Jurczyk-Romanowska (head of the Group), Dariusz Błaszczak, Agnieszka Gil, Joanna Golonka-Legut, Jacek Gulanowski, Piotr Gulanowski, Luba Jakubowska, Marta Koszczyc, Dagmara Łupicka-Szczęśnik, Aleksandra Marcinkiewicz, Natalia Romanowska, Magdalena Wnuk-Olenicz and Ilona Zakowicz - for their help in preparing the theoretical background of the experiment and the interpretation of its results. 


\section{References}

Active ageing and solidarity between generations. A statistical portrait of the European Union 2012 (2011). Luxembourg: Publications Office of the European Union.

Coldwell J. C. (2006). Demographic transition theory. Dordrecht: Sringer.

Czerniawska, O. (2007). Szkice z andragogiki i gerontologii [Essays on andragogy and gerontology], Łódź:Wydawnictwo Wyższej Szkoły Humanistyczno-Ekonomicznej .

Frąckiewicz, E.,(2009). Wpływ internetu na aktywność seniorów z punktu widzenia strategii budowania społeczeństwa informacyjnego i2010 [The effect of internet on the acitivity of seniors from the perspective of the strategy of building a society of knowledge i2010], Warszawa: Centrum Europejskie Natolin.

Halicka, M. \& Halicki J. (2003). Integracja społeczna i aktywność ludzi starszych [Social integration and the activity of older persons], In: B. Synak (ed.), Polska Starość [Polish Old Age], Gdańsk:Wydawnictwo Uniwersytetu Gdańskiego.

Information and Communication Technology (2008). Retrieved from: http://foldoc.org/Information+and+Communication+Technology

Murray J. (2011). Cloud network architecture and ICT. Retrieved from: http://itknowledgeexchange.techtarget.com/modernnetwork-architecture/cloud-network-architecture-and-ict/

Niezabitowski M. (2007). Ludzie starsi w perspektywie socjologicznej [Older people in sociological perspective], Katowice:"Śląsk" Wydawnictwo Naukowe.

Okólski M. (1997). Demograficzno-instytucjonalne antynomie współczesności [Demographic-institutional antinomies of modernity]. In: J. Reykowski, T. Bielicki (Eds.). Dylematy współczesnej cywilizacji a natura człowieka [The dilemma of modern civilisation and the nature of man], (pp. 22-55). Poznań: Wydawnictwo Zysk i sp.

Selwyn, N., Gorard, S. \& Furlong, J., (2006), Adult Learning in the Digital Age. Information technology and the learning society, London-New York: Routledge.

Semków, J. (2000). Wielość wymiarów przestrzeni życiowej ludzi w III wieku [The multiplicity of dimensions of the life space of people in 3rd age]. In: M. Dzięgielewska (ed.), Przestrzeń życiowa i społeczna ludzi starszych [Life and social space of older people], Łódź:Akademickie Towarzystwo Andragogiczne.

Semków, J. (2003). Społeczne oraz kulturowe wymiary przeżywanie okresu późnej dorosłości [Social and cultural dimensions of experiencing late adulthood. In: B. Synak (ed.),Polska Starość [Polish Old Age], Gdańsk: Wydawnictwo Uniwersytetu Gdańskiego.

Szarota, Z. (2004). Gerontologia społeczna i oświatowa: Zarys problematyki [Social and educational gerontology: Outline of problems], Kraków:Wydawnictwo Naukowe Akademii Pedagogicznej.

Victor, C., Scambler, S. \& Bond, J.,(2009).The Social World of Older People, Berkshire, UK: Open University Press.

World Population Aging. (2013). New York: United Nations.

Zach, A. (red.) (2001). Demograficzne i indywidualne starzenie się [Demographic and individual aging], Kielce: Wydawnictwo Akademii Świętokrzyskiej.

Ziębińska, B. (2010). Uniwersytety Trzeciego Wieku jako instytucje przeciwdziałające marginalizacji osób starszych [Universities of Third Age as institutions counteracting the marginalisation of older persons], Katowice: Śląsk.

\section{Additional Tables}

Table 2. Results of Multivariate Tests for the indicators of effectiveness (the pace of assimilation of the knowledge and the level of self-reliability of the participants) related to the method of teaching

\begin{tabular}{|c|c|c|c|c|c|}
\hline Effect & Value & $\mathrm{F}$ & Hypothesis df & Error df & Sig. \\
\hline
\end{tabular}


Wilks' Lambda

,372 17,256b

5,000

51,000

, 000

Table 3. Results of test of Between-Subjects Effects for the indicators of perception of the class related to the method of teaching

\begin{tabular}{|lllccc|}
\hline Source & Dependent variable & Type III Sum of Squares & df Mean square & F & Sig. \\
\hline Method & Attractiveness &, 127 & 1,127 &, 093 &, 761 \\
& Usefullness &, 186 & 1,186 &, 106 &, 746 \\
& Difficulty & 2,204 & 12,204 & 1,579 &, 214 \\
& & & & & \\
\hline
\end{tabular}

